IJOTL TL, Vol. 3, No. 3, September 2018

p ISSN: 2502 2326; e ISSN: 2502 8278

Http://ijolt1.pusatbahasa.or.id; Email: ijolt1@gmail.com

Center of Language and Culture Studies, Surakarta, Indonesia

Astia, Meirina. 2018. Corrective Feedback in English Class.

IJOTL TL (2018), 3(3): 111 122. DOI: 10.30957/ijotl tl.v3i3.502.

\title{
CORRECTIVE FEEDBACK IN ENGLISH CLASS
}

\author{
Meirina Astia \\ Mulawarman University, Samarinda \\ Email: meirinastia@yahoo.com
}

\begin{abstract}
The design of this study was classroom based observation research. The focus of this study was corrective feedback made by English teachers in the classroom. This study identified occurrences of the correction during the daily conversation course and the way teachers performed the corrective feedback in the classroom. Data were presented under the descriptive way and analyzed inductively in terms of features and facts of teacher's teaching process (teacher's corrective feedback). The study revealed that teacher's corrective feedback is one factor that influences the progress of students in learning English. It did not bother the students in building a communication. The evidence showed that that the teacher applied recasts, explicit correction, and clarification requests. Recasts was dominated the type of corrective feedback used by the teacher because it did not make the students confused. Three criteria of effective corrective feedback occurred in correction given by the teacher. He was consistent in treating the errors, gave correction without breaking the flow of the communication, and did not ridicule the students in giving correction.
\end{abstract}

Keywords: corrective feedback, classroom based research.

DOI: $10.30957 /$ ijotl tl.v3i3.502

\section{INTRODUCTION}

To facilitate successful language learning, teachers must perform a complicated balancing act of two necessary but seemingly contradictory roles. They must establish positive affect among students, yet also engage in the inherently confrontational activity of corrective feedback on error (Magilow, 2005). The positive affect derives from a variety of teachers behaviours, including humour, encouragement, personal interest, and a natural use of language. Corrective feedback conveys, in many ways, precisely the opposite messages confrontation, potential discouragement, and a focus on forms instead of content

In teaching L2, it is necessary to response toward the students' speech production as one of many ways to show the attention of the teacher to the students. Feedback is an important thing in English Communicative Teaching Learning Activities. During the activities the students somehow involved in an interaction that gives opportunities, desires and purposes which is able to empower the students to get in touch with the language they learn. This English classroom interaction will lead the students to do their 
IJOTL TL, Vol. 3, No. 3, September 2018

p ISSN: 2502 2326; e ISSN: 2502 8278

Http://ijolt1.pusatbahasa.or.id; Email: ijolt1@gmail.com

Center of Language and Culture Studies, Surakarta, Indonesia

Astia, Meirina. 2018. Corrective Feedback in English Class.

IJOTL TL (2018), 3(3): 111 122. DOI: 10.30957/ijot1 tl.v3i3.502.

best toward the target language. Along with these activities, teachers are allowed, to indicate the students' errors of incorrectness of language output, which is technically known as corrective feedback (Lightbown and Spada, 1994).

According to Lightbown and Spada (1994), there are two ways to conduct the corrective feedback: (1) explicit corrective feedback that is language teacher interrupts student's utterance by giving metalinguistic explanation, and (2) implicit corrective feedback that is language teacher interrupts student's utterance by giving some language input with no metalinguistic explanation. These kinds of feedback might be found during the English classroom communicative activities. If a teacher indicates the students' error through the implicit corrective feedback and the students can understand the feedback, then the students will be able to correct their language output themselves. However, if the students cannot understand the teacher's implicit corrective feedback then, they will probably preserved with the explicit corrective feedback by the teacher. Perhaps, the students may correct their language output under the teacher's intervention.

Corrective feedback is given by the teachers when the students use the target language incorrect. The students' errors are expected to be improved after they get the correction. Learners' errors could be grammatical errors such as the incorrect use of preposition, pronoun or tenses; lexical errors such as nouns, verbs or adjectives; and phonological errors.

Many research findings on corrective feedback were shown by the scientists. In order to discuss the contribution corrective feedback can make to L2 acquisition. De Keyser's (1993) result study indicated that some students did benefit from the corrective feedback. De Keyser found that, after the feedback treatment, (a) students with high pretest scores did better on a written grammar post-test; (b) students with low extrinsic motivation did better on oral accuracy and oral fluency post-test measures; and (c) student with low anxiety did better on a written grammar post test.

In researcher's opinion, it is also important to figure out what kind of corrective feedback the teachers apply in teaching L2, their expectation in giving correction, and somehow, the teachers do not know the term "corrective feedback" itself. Based on the fact above, the researcher is interested to do the research on English teachers' corrective feedback in a Speaking Class.

Related to the research, the researcher would like to conduct a Classroom Research on English Teachers' corrective feedback in speaking classes. The classroom research is chosen because it is considered the practical research in the classroom that will be conducted by the teacher. Besides, by doing the classroom action research, the researcher is able to get the real information on what the teachers do. This research emphasizes on the English teachers' corrective feedback in speaking class. The study was focused to (1) types of corrective feedback, and (2) teacher's conducts in presenting corrective feedback in speaking class.

\section{METHODS}

The design of this study was Classroom Research Design. The classroom research involved a process of involving teachers in the formal study of teaching and learning. It attempted to answer two fundamental questions: how well are students learning and 
IJOTL $\sim$ TL, Vol. 3, No. 3, September 2018

p ISSN: 2502 2326; e ISSN: 2502 8278

Http://ijolt1.pusatbahasa.or.id; Email: ijolt1@gmail.com

Center of Language and Culture Studies, Surakarta, Indonesia

Astia, Meirina. 2018. Corrective Feedback in English Class.

IJOTL TL (2018), 3(3): 111 122. DOI: 10.30957/ijot1 tl.v3i3.502.

how effectively are teachers teaching. Trough close observation, the collection of feedback on student learning and the careful design of experiments, classroom teachers was able to learn more about how students learn, and more specifically, how students responded to particular teaching approaches (Cross and Angelo, 1988).

The focus of this was to improve one specific point in a teacher's technique in a particular classroom using empirical measurement. Richards, Platt \& Platt (1992) defined teacher-initiated classroom research seeks to increase the teacher's understanding of classroom teaching and learning and to bring about improvements in classroom practices. Action research typically involved small-scale investigated projects a in the teacher's own classrooms. This usually included having an observer collect data, and together with the teacher to develop a plan to bring about the desired change, acts on the plan, and then observes the effects of the plan in the classroom.

In addition, Budiharso (2004) admitted that classroom action research is the research held in the classroom using the classroom setting. The research explained what really happened in the classroom. Further, Budiharso (2004:165) states that classroom research is done by the linier process and finished at once.

The focus of this study was corrective feedback made by English teachers in the classroom. In this study, the researcher identified occurrences of the correction during the speaking class and the way teachers performed the corrective feedback in the classroom. Data were presented under the descriptive way and analyzed inductively in terms of features and facts of teacher's teaching process.

\section{RESULTS}

Findings of the study are written and directed to know types of corrective feedback present on speaking class in the English Department at Unikarta Tenggarong and analyze the way teacher conducts the corrective feedback. In analyzing the perform of the corrective feedback, the researcher adopted three criteria for effective and efficient corrective feedback by Mendelson, they are selective corrective feedback, choose productive items, and correct constructively.

\subsection{Types of Corrective Feedback}

The result of observation showed that teacher entered the class for six meetings.

From the first to sixth meeting the teacher ran the lecture well. And he also gave the correction to the student effectively. He combined three types of corrective feedback, those are recasts, explicit correction, and clarification.

\section{a. Recasts}

Recasts involved the teacher's reformulation of all part of a students' utterance minus the error. Excerpts below exemplify recasts used by the teacher:

(1) S : “It's about Sam's birthday party.

If we look at ... ee ... on the wall.

There is a picture of family Sam"

$\mathrm{T}$ : $\quad$ "Sam's family" (first meeting) 
(2) S2: "a man is offering a hamburger to a woman and said "I'm not eat meat"

$\mathrm{T}: \quad$ "I don't eat meat" (first meeting)

Those samples of recasts show that the teacher reformulated the students' utterance without repeating the error when the student made grammatical errors. Recasts are generally implicit in that they are not introduced by phrase such as "you mean," "use this word," or "you should say." See excerpt (3) for the example.

$$
\begin{array}{ll}
\mathrm{S} 1: & \text { "refused it because vegetarian.. I think.." } \\
\mathrm{T}: & \text { "ah.. she's a vegetarian" (first meeting) }
\end{array}
$$

Here, the teacher only provided the correct form of students' utterances, even the utterance was not totally incorrect, and he did not use those phrases to realize the students what he said is incorrect. The researcher thought there was a subjectivity of the teacher in seeing an error.

Recasts also include translations in response to a student's use of the L1. See the quotations on scripts (4) and (5).

$$
\begin{array}{ll}
\mathrm{S}: & \text { "ehm... a book, lamp, toy spider..” } \\
\mathrm{T}: & \text { "spider toy" (third meeting) } \\
\mathrm{S}: & \text { "... the function of A tuts is to give a high ball" } \\
\mathrm{T}: & \text { "tuts A" (fifth meeting) }
\end{array}
$$

Sometimes the students made error because the influences of mother tongue. Even the teacher understood the meaning of student's utterance, he gave correction to it. The researcher found that the use of recasts dominated almost in all meetings. The teacher seldom made correction with complete explanation. It was considered he did not want to break the flow of communication.

\section{b. Explicit Correction}

It refers to the explicit provision of the correct form. As the teacher provides the correct form, he or she clearly indicated that what the students had said was incorrect. (e.g. "you mean..," "you should say..."). See script (6) for the example.

(6) S : “and the Sam's wife offering the man. But the man refusing...

T : “ah... you mean he doesn't drink coffee" (first meeting)

The teacher considered what the student had said was incorrect when he just said "the man refusing..." On researcher's mind, the error was not really significant because the teacher could understand the meaning but it was grammatically incorrect. Here, the researcher thought there was a subjectivity of the teacher's mind in seeing the errors. 
IJOTL TL, Vol. 3, No. 3, September 2018

p ISSN: 2502 2326; e ISSN: 2502 8278

Http://ijolt1.pusatbahasa.or.id; Email: ijolt1@gmail.com

Center of Language and Culture Studies, Surakarta, Indonesia

Astia, Meirina. 2018. Corrective Feedback in English Class.

IJOTL TL (2018), 3(3): 111 122. DOI: 10.30957/ijotl tl.v3i3.502.

But in excerpt (6) there was no repetition from the student. In contrast with the quotation below:

$$
\begin{array}{ll}
\mathrm{S}: & \text { "... maybe he is conversing... e... to..." } \\
\mathrm{T}: & \text { "makes a conversation kan maksudnya" } \\
\mathrm{S}: & \text { " makes a conversation... e... eee... to a woman..." (third } \\
& \text { meeting). }
\end{array}
$$

Quotation (7) showed that the student repeated what the teacher had corrected. The student uttered inappropriate to state what is on his mind, and the teacher tried to comprehend the word by providing the correct form while asking "..kan maksudnya?" to ensure him.

When the teacher gave correction explicitly, the researcher observed that the students were aware then they are being corrected because the teacher clearly indicated what the students had said.

\section{c. Clarification Requests}

Clarification requests indicate to students either that their utterance has been misunderstood by the teacher or that the utterance is ill-formed and that a repetition or a reformulation is required. Script (8) exemplifies the model.

(8) S : "the man is offering hamburger to the woman but she don't want to eat meat...

T: "what did you say?"

S : "but she doesn't eat meat" (second meeting)

When the student made grammatical error, the teacher did not provide the appropriate form, he just paused the conversation by saying "what did you say?" and this correction worked well so that the student reformulated his utterance himself.

Sometimes, the teacher could not understand what the student had said. So, it was important to the teacher to ask the student. This is a type of feedback that can refer to problems in either comprehensibility or accuracy, or both. Clarification requests include phrases such as "pardon me?" and it may also include a repetition of the error as in "what do you mean by X?" For details, we can see the excerpt (9) below:

(9) S : "Inside, party attending from her friends..

$\mathrm{T}$ : $\quad$ "pardon me, what do you mean by party attending?

S : "Inside, they attending the party" (third meeting)

Here, the teacher clearly indicated that he did not understand what the students had said. The teacher also did not provide the correct form. But the student directly understood that his utterance was incorrect, and he repaired it himself. 
IJOTL $\sim$ TL, Vol. 3, No. 3, September 2018

p ISSN: 2502 2326; e ISSN: 2502 8278

Http://ijolt1.pusatbahasa.or.id; Email: ijolt1@gmail.com

Center of Language and Culture Studies, Surakarta, Indonesia

Astia, Meirina. 2018. Corrective Feedback in English Class.

IJOTL TL (2018), 3(3): 111 122. DOI: 10.30957/ijot1 tl.v3i3.502.

The researcher found that the student's ability to comprehend the correction was not same. The quotation below showed that the student did not understand the correction from the teacher in English. The teacher repeated in Indonesian to make the student understand. See excerpt (10) for the example.

(10) S : "how custom to free kick?"

$\mathrm{T}$ : "what do you mean?...what do you mean?"

S : "what do you mean?"

T: "maksudmu apa?"

S: “anu..bagaimana cara menendang tendangan bebas?"

T : " "ooh..how to do the free kick?" (fifth meeting)

From excerpt (10), the researcher thought that the student did not know that he was being corrected while he repeated the teacher's utterance and finally, the teacher used Indonesian in giving correction.

\subsection{Teacher Performs Corrective Feedback}

In analyzing the way teacher performs the corrective feedback, the researcher borrowed three criteria for efficient and effective corrective, correct selectively, choose productive items, and correct constructively from Mendelson (in Salikin, 2001).

\section{a. Selective Corrective Feedback}

It is impossible for the teachers to correct all the errors students make. It was proven on the Speaking Class being observed. The teacher did not correct all the students error, sometime he just ignored some errors. Examples of Selective Corrective Feedback appear on excerpts (11) and (12).

(11) S : "because...the...because the... in hers bag

$\mathrm{T}$ : $\quad$ "there is..." (second meeting)

(12) S : "I usually using joystick in PS2..." (fifth meeting)

Excerpts (11) and (12) showed that sometimes teacher tolerated the grammatical errors made by the student. The researcher believed that when the students are overcorrected they may become discouraged and confused, when the researcher interviewed the teacher in regard with his way in giving correction, he stated. See excerpt (13).

(13) "in giving correction, I try not to make negative effect to the students, and I don't give the correction to all errors, especially when the error did not break the communication."

Hendrickson (in Salikin, 2001) believes that the learners do not like to be corrected for each errors they made because this practise destroy their confidence to use the target language. Based on the observation, the researcher assumed that the 
IJOTL TL, Vol. 3, No. 3, September 2018

p ISSN: 2502 2326; e ISSN: 2502 8278

Http://ijolt1.pusatbahasa.or.id; Email: ijolt1@gmail.com

Center of Language and Culture Studies, Surakarta, Indonesia

Astia, Meirina. 2018. Corrective Feedback in English Class.

IJOTL TL (2018), 3(3): 111 122. DOI: 10.30957/ijot1 tl.v3i3.502.

correction from the teacher did not break the flow of communication, because the teacher give the correction in the right time without giving explanation in the middle of communication. We can see the excerpt (14) below:

$$
\begin{aligned}
& \mathrm{S}: \quad \text { "this is happy birthday Sam" } \\
& \mathrm{T}: \quad \text { "Sam's birthday party" } \\
& \mathrm{S}: \quad \text { "Sam's birthday party. Many and friends and family to be an } \\
&
\end{aligned}
$$

On researcher's mind, as a learner, sometime the students do not care about accuracy as long as they get the message across. It is important for them to understand the meaning of their fiends' utterances.

\section{b. Choice of Productive Items for Correction}

The decision as to what to correct should be based on the rule that the teachers should concentrate on that will be most productive for the learners' future communication. This is not an easy job for the teachers usually are not consistent in treating errors.

In this study, the researcher observed the teacher tried to give the correction toward the lesson materials which are expected have been mastered by the students. Look at the excerpts (15), (16), (17), and (18) below:

$$
\begin{array}{ll}
\mathrm{S}: & \text { "... there is a picture of family Sam" } \\
\mathrm{T}: & \text { "Sam's family" (Recasts) (First meeting) } \\
\mathrm{S}: & \text { "It is picture Princess" } \\
\mathrm{T}: & \text { "Princess' picture” (Recasts) (second meeting) } \\
\mathrm{S}: & \text { "suddenly a man using a black glasses enter the office to } \\
& \text { send five box of pizza" } \\
\mathrm{T}: & \text { "five boxes of pizza" (recasts) (third meeting) } \\
\mathrm{S}: & \text { "and there, there teacher English" } \\
\mathrm{T}: & \text { "you mean, there is an English teacher" (explicit correction) } \\
& \text { (Third meeting) }
\end{array}
$$

Those four excerpts (15), (16), (17), (18) show that the teacher concentrated to the simple errors that should have been mastered by the students, and those errors occurred frequently in learner's speaking, so the teacher did not have to give detail explanation. And the students realized that they had uttered incorrect form. The quotation below shows that sometimes the teacher gave correction when he did not get the meaning of the students' utterance.

$$
\begin{array}{ll}
\mathrm{S}: & \text { "... party attending from her friends.” } \\
\mathrm{T}: & \text { "pardon me? What do you mean by party attending?" } \\
& \text { (clarification requests) (Third meeting) }
\end{array}
$$


IJOTL $\sim$ TL, Vol. 3, No. 3, September 2018

p ISSN: 2502 2326; e ISSN: 2502 8278

Http://ijolt1.pusatbahasa.or.id; Email: ijolt1@gmail.com

Center of Language and Culture Studies, Surakarta, Indonesia

Astia, Meirina. 2018. Corrective Feedback in English Class.

IJOTL TL (2018), 3(3): 111 122. DOI: 10.30957/ijotl tl.v3i3.502.

Errors that impair the communication significantly which are shown in excerpt (19) need a correction from the teacher immediately.

\section{c. Constructive Error Correction}

Creating a very good atmosphere in the classroom is very essential to gain the successful language learning, the classroom atmosphere should be built on a premise of mutual respect. This means learners and the teachers should respect each other. The researcher observed that when the teacher gave correction to the students he did not make the students feel fear or ridicule. Within six meetings, the researcher saw that the students kept talking even though they got correction from the teacher. And other students did not laugh at anyone when a student made a mistake. Sometimes other student helped his friend when a student uttered incorrect form. The quotation (20) below is the example:

$$
\begin{aligned}
& \text { S : "yes, how to play is hard for me...my finger is not able for } \\
& \text { T : "oohe key....keyboard... }
\end{aligned}
$$

In regard with laughing at anyone, they have special tradition when someone made a mistake whether in a competition or presentation or in learning activities, they give applause to him or her. It does not mean they humiliate the student, but it is one way to support him or her. So, when a student is being corrected, he or she is expected not to feel ashamed. This tradition has been applied since the first time. It makes the class environment safe to take risk for the student to try thing out without fear or ridicule.

\subsection{Result of Interview}

The result of interview was applied to clarify more details information on these questions: (1) Which errors should be corrected?, (2) When errors should be corrected?, and (3) How should errors be corrected?"

The researcher got the fact on the field that the teacher always gave correction simple errors such as use of possessive, simple present tense, and word orders. When the researcher confirmed it to the teacher, he agreed and explained that he gives correction for these reasons, first, if the errors break the meaning of students utterance so his friends or himself can not get the meaning across. Second, he always gives the correction for the simple errors which should have been mastered by the students, and also for the errors which need correction based on his point of view that students' utterance was wrong.

The right time in giving correction contributes positive effects toward the students on response to their ill-form of target language they made. The researcher had observed that the teacher could give the correction well and in the right time. To ensure this assumption, she clarified it to the teacher about the timing in giving correction. He 
IJOTL TL, Vol. 3, No. 3, September 2018

p ISSN: 2502 2326; e ISSN: 2502 8278

Http://ijolt1.pusatbahasa.or.id; Email: ijolt1@gmail.com

Center of Language and Culture Studies, Surakarta, Indonesia

Astia, Meirina. 2018. Corrective Feedback in English Class.

IJOTL TL (2018), 3(3): 111 122. DOI: 10.30957/ijot1 tl.v3i3.502.

stated that he usually gives correction to his students when they are involved in communication process in English learning activities. He added that he tends to give the correction in the right time otherwise the correction will disturb student' utterance and flow of communication. Besides, he said further, overcorrected is not good for the students.

Based on the observation within six meetings, the researcher found that the teacher never gave a detail correction and complete explanation toward the students' errors in the middle of communication. He coined that he doesn't want to give negative effect to the students in giving correction, by means of simple word and without giving details explanation. But he tried to give the information and correction at the end of meeting. He assumed that this is a good way to concentrate the error and repair it all at once. He added that when he gives correction, it depends on student's ability to comprehend the correction. So, he doesn't correct all students who made the same errors, but he tries to consider their ability.

\section{DISCUSSION}

The finding of the study showed types of corrective feedback used by the teacher included recasts, explicit correction, and clarification requests. Teacher performed corrective feedback by selecting corrective feedback, choosing productive items for correction, and making a constructive error correction. But, it is necessary to discuss the classroom setting first based on the researcher's field notes.

This study took place on Speaking Class of English Department at Unikarta Tenggarong. Speaking Class was one of the lectures in one semester, and it was given at the second semester. For the first semester they learned basic English which was dominated by $70 \%$ of theory and the rest was for practice. When the students were in second semester they had $70 \%$ practise with less theory that they built on Speaking Class. The students were expected to have a good skill in English. This class consisted of 38 students with $70 \%$ men.

The Speaking Class was held three times a week every Tuesday, Wednesday, and Thursday at 11 a.m. The classroom was set as comfortable as possible by the management team. It was a large classroom with air conditioner and good lighting. It was not a big problem when the students had to study in the middle of the day or at night. The conditions were still comfortable to study. The other facilities were television, VCD, OHP, and in-focus which were accessible for the teachers to vary the teaching learning activities. Within six meetings the teacher gave the students two materials to be discussed. First, the teacher provided a copy of picture and the students described and explained the activities on the picture. The communication ran between teacher and each student. For the second materials, the teacher brought the topic about Information Technology to the class. The students were very enthusiastic toward this topic, because it was their specialization and they knew a lot about it. Here, the teacher ordered them to make their own dialogue without teacher's intervention.

The findings showed that the teacher applied three types of corrective feedback. Within six meeting, recasts almost dominated the error correction from the teacher. According to Lyster and Ranta, recast involved the teacher's reformulation of all part of 
IJOTL $\sim$ TL, Vol. 3, No. 3, September 2018

p ISSN: 2502 2326; e ISSN: 2502 8278

Http://ijolt1.pusatbahasa.or.id; Email: ijolt1@gmail.com

Center of Language and Culture Studies, Surakarta, Indonesia

Astia, Meirina. 2018. Corrective Feedback in English Class.

IJOTL TL (2018), 3(3): 111 122. DOI: 10.30957/ijotl tl.v3i3.502.

a student's utterance, minus the error. Continued with explicit correction and the least was clarification requests. Teacher considered that those three types are as effective ways in giving correction. It is possible for the teacher to give other type of corrective feedback on previous meetings, or perhaps for the next meetings. By giving recast means the teacher provided the correct answer or the right form. According to Lyster and Ranta, recast involved the teacher's reformulation of all part of a student's utterance, minus the error. It is believed that when the teacher gave the right answer, the students were not confused. They directly recognized that their answers were wrong.

Concerning the teacher performance on corrective feedback, it showed that the teacher conducted it well. He used simple word and tolerated some ill-form of the students' utterances. The teacher provided the corrective feedback for the sake of the learners. In normal communication, even when people talking in their mother tongue, linguistic errors often exist without breaking the communication. It is a conventional wisdom not to destroy the flow of the communication by stopping the learners to correct them. The teacher avoided interrupting communicative exchange. The correction did not make the students lose their face so that they did not mind to keep talking in target language. The corrections were not frightening for the students so that the teacher didn't have to work hard to make them speak. Mendelson (in Salikin) coined that the speaking class should be a sheltered environment in which it is always safe to take risk for the students to try everything out without fear or ridicule. By this the learner might be more confident to use the language they are learning. But still there are some weaknesses. Sometimes the teacher just let the error away, even it needed a correction. The teacher also provided the correction in target language. Sometimes the correction in L1 is necessary to be used by the teacher to clarify his correction.

This study showed that different types of corrective feedback applied by the teacher did not break the flow of the communication. And the students seemed they did not mind to be corrected by the teacher proven by they kept to continue talking in target language. Related to earlier studies, the evidences of this research support the earlier studies. The result of the previous study by Daniel H. Magilow showed that students did not seem at all offended or disturbed by corrective feedback, some not only did not mind correction but wanted it and noticed its absence. Another study by Syahiddin showed that the learners thought their English teacher's explicit correction is a normal thing and they believe that it is one of the important things in English teaching learning activities.

\section{CONCLUSION}

Relying upon the findings, discussion and purpose of the study, the researcher can draw the conclusion as the following:

1. Teacher's corrective feedback is one factor that influences the progress of the students in learning English. It did not bother the students in building a communication. The evidence showed that that the teacher applied recasts, explicit correction, and clarification requests. Recasts was dominated the type of corrective feedback used by the teacher because it did not make the students confused. 
IJOTL TL, Vol. 3, No. 3, September 2018

p ISSN: 2502 2326; e ISSN: 2502 8278

Http://ijolt1.pusatbahasa.or.id; Email: ijolt1@gmail.com

Center of Language and Culture Studies, Surakarta, Indonesia

Astia, Meirina. 2018. Corrective Feedback in English Class.

IJOTL TL (2018), 3(3): 111 122. DOI: 10.30957/ijot1 tl.v3i3.502.

2. Three criteria of effective corrective feedback occurred in correction given by the teacher. He was consistent in treating the errors, gave correction without breaking the flow of the communication, and did not ridicule the students in giving correction.

\section{REFERENCES}

Al-Wasilah, A. Chaedar. 2002. Pokoknya Qualitative. Jakarta: Pustaka Jaya.

Andriany, D. 2004. The Study on Speaking Class of the Tourism Program of the Third Year Students of SMKN 1 Tenggarong. Thesis. Samarinda: College of Education, Mulawarman University.

Bogdan \& Biklen. 1992. Qualitative Research for Education (2 ${ }^{\text {nd }}$ edition). Massachusetts: Allyn and Bacon, Needham Heights.

Budiharso, T. 2004. Prinsip dan Strategi Pengajaran Bahasa. Surabaya: Penerbit Lutfansyah Mediatama.

Budiharso, T. 2006a. English Language in Teaching, Discourse Analysis, and Contrastive Rhetoric. Yogyakarta: Stepapublishing.

Budiharso, T. 2006b. Pengajaran Bahasa Berbasis Konteks dalam Perspektif Analisis Wacana dan Linguistik. Surakarta: Penerbit Pustaka Cakra.

Budiharso, T. 2006c. Pengantar Penulisan Karya Ilmiah. Samarinda: Penerbit Certelbooks.

Crane, S. Level of Feedback, http://coe.sdsu.edu/eet/articles/lofeedback/start.htm . (retrieved on February, 15th 2005).

Cross, K and Angelo. Classroom Research and Assessment, http://www.cariboo.bc.ca/pd/workshopdesc/classroom\%research\%20\&20assessme nt.html, (retrieved on February, $15^{\text {th }} 2005$ ).

Kim, Ji Hyun. 2005. Issues of Corrective Feedback in Second Language Acquisition, www.tc.columbia.edu/academic/tesol/webjournal/jihyunKim.pdf, (retrieved on November, $\left.15^{\text {th }} 2005\right)$.

Magilow, D.H. 2005. Case Study \#2: Error Correction And Classroom Affect, http://web.utk.edu/ germslav/uphome/1999cPrize.html, (retrieved on November, $\left.15^{\text {th }} 2005\right)$.

Miles, Huberman, Michael.1994. Qualitative Data Analysis: An Expanded sourcebook, California: Sage Publication.

Patton, Michael Quenn. 1990. Qualitative Evaluation and Research Methods, California: Sage Publication.

Salikin, H. 2005. Correcting Errors in the Communicative Speaking Class, http://www.unej.ac.id/fakultas/sastra/sasra_en/jurnal/vol-02/hairus.pdf, (retrieved on November, $15^{\text {th }} 2005$ ).

Sudikin, Basrowi, Suranto. 2002. Manajemen Penelitian Tindakan Kelas, Jakarta: Insan Cendikia.

Syahiddin. 2004. Students' Perception Toward Their English Teachers' Explicit Corrective Feedback on Form at the First Grade of SLTP Negeri 16 Samrinda in Academic Year 2002/2003. Thesis. Samarinda: College of Education, Mulawarman University. 
IJOTL TL, Vol. 3, No. 3, September 2018

p ISSN: 2502 2326; e ISSN: 2502 8278

Http://ijolt1.pusatbahasa.or.id; Email: ijolt1@gmail.com

Center of Language and Culture Studies, Surakarta, Indonesia

Astia, Meirina. 2018. Corrective Feedback in English Class.

IJOTL TL (2018), 3(3): 111 122. DOI: 10.30957/ijotl tl.v3i3.502. 